\title{
Experimental ophitoxemia produced by the opisthoglyphous lora snake (Philodryas olfersii) venom
}

\author{
Ofitoxemia experimental produzida pelo veneno da serpente \\ opistoglifa lora (Philodryas olfersii)
}

\author{
Alexis Rodríguez-Acosta ${ }^{1}$, Karel Lemoine ${ }^{1}$, Luis Navarrete ${ }^{1}$, \\ María E. Girón ${ }^{1}$ and Irma Aguilar ${ }^{1}$
}

\begin{abstract}
Several colubrid snakes produce venomous oral secretions. In this work, the venom collected from Venezuelan opisthoglyphous (rear-fanged) Philodryas olfersii snake was studied. Different proteins were present in its venom and they were characterized by 20\% SDS-PAGE protein electrophoresis. The secretion exhibited proteolytic (gelatinase) activity, which was partially purified on a chromatography ionic exchange mono Q2 column. Additionally, the haemorrhagic activity of Philodryas olfersii venom on chicken embryos, mouse skin and peritoneum was demonstrated. Neurotoxic symptoms were demonstrated in mice inoculated with Philodryas olfersii venom. In conclusion, Philodryas olfersii venom showed proteolytic, haemorrhagic, and neurotoxic activities, thus increasing the interest in the high toxic action of Philodryas venom.
\end{abstract}

Key-words: Colubridae. Haemorrhage. Neurotoxic. Philodryas olfersii. Proteolytic activity. Venom.

\begin{abstract}
RESUMO
Várias serpentes da família Colubridae produzem secreções orais venenosas. Neste trabalho, foi estudado o veneno coletado da presa posterior da serpente opistóglifa venezuelana Philodryas olfersii. Deferentes proteínas estavam presentes no veneno, sendo caracterizadas pela eletroforese de proteínas (SDS-PAGE) a 20\%. A secreção mostrou atividade proteolítica (gelatinase) a qual foi parcialmente purificada em uma coluna de intercâmbio iônico (mono Q2). Adicionalmente, a atividade hemorrágica do veneno de Philodryas olfersii foi demonstrada em embriões de galinha, pele e peritônio de rato. Os sintomas neurológicos foram demonstrados em camundongos inoculados com veneno de Philodryas olfersii. Em conclusão, o veneno da Philodryas olfersii mostrou atividade proteolítica, hemorrágica, e neurotóxica, assim aumentando o interesse na elevada ação tóxica do veneno da Philodryas olfersii.
\end{abstract}

Palavras-chaves: Colubridae. Hemorragia. Neurotoxinas. Philodryas olfersii. Atividade proteolítica. Veneno.

Philodryas genus has 16 described species $^{8}$, of which five (baroni, chamissonis, olfersii, patagoniensis and viridissimus) have been reported to cause human envenomation $^{7152125}$. In an eight year study (1982-1990), of the 43 patients admitted to the Instituto Butantan, São Paulo, Brazil, diagnosed with $P$. olfersii bites, the most common clinical characteristics were local pain $(37.2 \%)$, swelling (34.9\%), erythema (18.6\%) and ecchymosis (9.3\%). The blood clotting test was performed on 11 patients and in all of them the blood was coagulable $e^{24}$. Other authors ${ }^{3}$ have reported cases of human envenoming by Philodryas, showing evidence of the clinical aspects and the evolution of the symptoms of envenoming. They called attention to the similarities of these cases with those caused by the Bothrops genus, suggesting a more careful evaluation of the victims. In spite of these human accidents, comparatively modest experimental consideration has been given to the toxic properties of the venom produced by these opisthoglyphous snakes. This secretion contain a mixture of enzymes ${ }^{6}$ that break down cellular organization and obstruct critical functions, such as aeration, the conduction of nervous signals and blood circulation. Analyses of some of these secretions have shown that enzymes such as phospholipase A

\footnotetext{
1. Immunochemistry Section, Instituto de Medicina Tropical "Felix Pifano", Universidad Central de Venezuela, Caracas, Venezuela. Address to: Dr. Alexis Rodríguez-Acosta, Apartado 47423, Caracas 1041, Venezuela

Tel: $58212605-3558$

e-mail: rodriguf@ucv.ve

Recebido para publicação em 16/8/2004

Aceito em 27/1/2006
} 
and L-amino acid oxidase are not rare in the colubrid secretions studied ${ }^{27}$. The main aim of this study was to generate information regarding Colubridae Philodryas olfersii venom, thus increasing the interest in the enzymatic activities present in the toxins of this snake venom and alert physicians that this colubrid could present a serious problem for human health.

\section{MATERIAL AND METHODS}

Animals. Albino Swiss NIH strain male mice weighing 18-22g maintained under laboratory conditions and obtained from the National Institute of Hygiene "Rafael Rangel" were used. The investigation complied with the norms taken from the guide Principles of laboratory animal care ${ }^{2}$.

Snake captures were carried out during evening and crepuscular tours (without transect delimitations), in different geographical Venezuelan environments, with a high emphasis on those areas of interest for the study (San Juan de los Morros, Guárico state, Venezuela), where there were museum references of opisthoglyphous snake (Philodryas olfersii) incidences.

Venom. Venom was collected in a $50 \mathrm{~mL}$ plastic centrifugal tube transversely cut and covered on the top with parafilm. The snake was obliged to bite the parafilm with its opisthoglyphous fangs. The venom was milked with a capillary tube and immediately frozen in liquid nitrogen. From each milking, approximately $0.3 \mathrm{~mL}$ of secretion was obtained.

Protein determination. The protein determination method followed that of Lowry et al ${ }^{18}$.

Sodium dodecyl sulphate-polyacrylamide gel electrophoresis. Electrophoresis using a Dual Mini Slam Kit AE-6450 (Atto Corporation, Tokio, Japan) chamber was performed. SDS-PAGE was carried out according to the Laemmli method ${ }^{16}$, using $20 \%$ gels under reducing conditions. Molecular weight markers (Bio-Rad) were run in parallel and the gels were stained with Coomassie Blue R-250. The Philodryas olfersii venom samples under analysis were dissolved at a proportion of 1:1 in the solubilizer solution: 0.5M Tris.HCl, pH 6.8, with 10\% (w/v) SDS, 10\% (v/v) ß-mercaptoethanol, 10\% (v/v) glycerol and $0.05 \%(\mathrm{w} / \mathrm{v})$ bromo phenol blue, and heated at $100^{\circ} \mathrm{C}$ for 10 minutes. The molecular weight was determined by Multi-Analyst TM/ PC version 1.1 program (Bio-Rad).

Chromatographic analysis. Philodryas olfersii venom (20mgrs) was diluted to $1.0 \mathrm{~mL}$ with $50 \mathrm{mM}$ Tris- $\mathrm{HCl}$, buffer $\mathrm{pH}$ 7.0 and exposed to Mono Q2 column chromatography preequilibrated with the same buffer at $4^{\circ} \mathrm{C}$. The column was washed with three column volumes of equilibrating buffer at a flow rate of $1.0 \mathrm{~mL} / \mathrm{min}$. Venom proteins were eluted with a gradient of $0-1 \mathrm{M} \mathrm{NaCl}$ dissolved in $50 \mathrm{mM}$ Tris- $\mathrm{HCl} \mathrm{pH} \mathrm{7-9.} \mathrm{The}$ fraction size was $0.5 \mathrm{~mL}$. Protein elution was monitored at $280 \mathrm{~nm}^{1}$. The eluting peaks were tested for proteolytic activity.
Haemorrhagic activity tested on chicken embryos. Embryonic hen eggs incubated at $37^{\circ} \mathrm{C}$ for five days were cleansed with $70 \%$ alcohol and the embryos extracted by breaking the eggshells. The embryos were placed on petri dishes and incubated at $37^{\circ} \mathrm{C}$ for three hours.

Circles of filter paper Watmann $\mathrm{N}^{\circ} 2$ of $3 \mathrm{~mm}$ diameter were impregnated with $3 \mu \mathrm{L}(24 \mu \mathrm{g})$ of venom and applied to the chicken embryo vitelline vein ${ }^{22}{ }^{26}$. Circles soaked with $3 \mu \mathrm{L}$ $(7.5 \mu \mathrm{g})$ of Bothrops venezuelensis venom were used as a positive control and saline solution was used as a negative control.

Determination of haemorrhagic activity on mouse skin. Philodryas olfersii venom haemorrhagic activity was determined by a modification of Kondo's test ${ }^{10}{ }^{14}$. One hundred microlitres of venom containing $5-50 \mu \mathrm{g}$ were injected intradermal into the abdominal skin of four male NIH Swiss albino mice. The skins were removed after six hours and the haemorrhagic spot diameters on the inside surfaces were measured ${ }^{11}$. Two diameters were registered for the haemorrhage spot by measuring the longest diameter of the spot and the diameter perpendicular to the first measurement. A minimal haemorrhagic dose (MHD) was taken as the end point and defined as the concentration of venom resulting in a $10 \mathrm{~mm}$ haemorrhagic spot ${ }^{5}$. Bothrops venezuelensis venom $(50 \mu \mathrm{L}$ of $5.6 \mu \mathrm{g} / 20 \mathrm{~g}$ of mouse weight) and saline solution were used as positive and negative controls, respectively.

Determination of haemorrhagic activity on mouse peritoneum. One hundred $\mu \mathrm{L}$ of Philodryas olfersii venom containing $28 \mu \mathrm{g} / 20 \mathrm{~g}$ of mouse weight were injected intraperitoneally into four male NIH Swiss albino mice. Bothrops venezuelensis venom $(50 \mu \mathrm{l}$ of $5.6 \mu \mathrm{g} / 20 \mathrm{~g}$ of mouse weight) and saline solution were used as positive and negative controls, respectively.

Neurotoxic activity. To determine the neurological signs and symptoms which may be produced by Philodryas olfersii venom, six mice were subcutaneously injected with venom $0.1 \mathrm{~mL}(5.6 \mu \mathrm{g} / 20 \mathrm{~g}$ of mouse weight $)$ and clinically observed.

Gelatinase assay. An assay modified from Huang and Pérez ${ }^{112}$ was used to test the gelatinase activity of Philodryas olfersii venom. The X-ray film was washed down with distilled water and incubated at $37^{\circ} \mathrm{C}$ for $45 \mathrm{~min}$. After incubation, the film was dried completely and twenty five microlitres of crude venom, as well as ion fractions obtained by chromatography at dilutions of 1 to $128(1.9 \mathrm{mg} / \mathrm{mL}$ solution) were placed on a Kodak X-OMAT scientific imaging film with gelatine coating. Hydrolysis of the gelatine on the X-ray film was determined after four hours of incubation at $37^{\circ} \mathrm{C}$ in a humid incubator by washing the film with distilled water.

Serial dilutions were performed to determine the minimum amount of venom required to cause a clear spot on the X-ray film. The titre was defined as the reciprocal of the highest dilution that caused a clear spot on the X-ray film. The specific gelatinase activity was calculated by dividing the titre by the amount of protein $(\mu \mathrm{g})$ applied to the film. The assay was repeated three times. 


\section{RESULTS}

Sodium dodecyl sulphate-polyacrylamide gel electrophoresis. The SDS-PAGE proteins present in Philodryas olfersii venom are shown in Figure 1. The relative masses were determined using the Multi-Analyst TM/PC version 1.1 (Bio-Rad) programs.

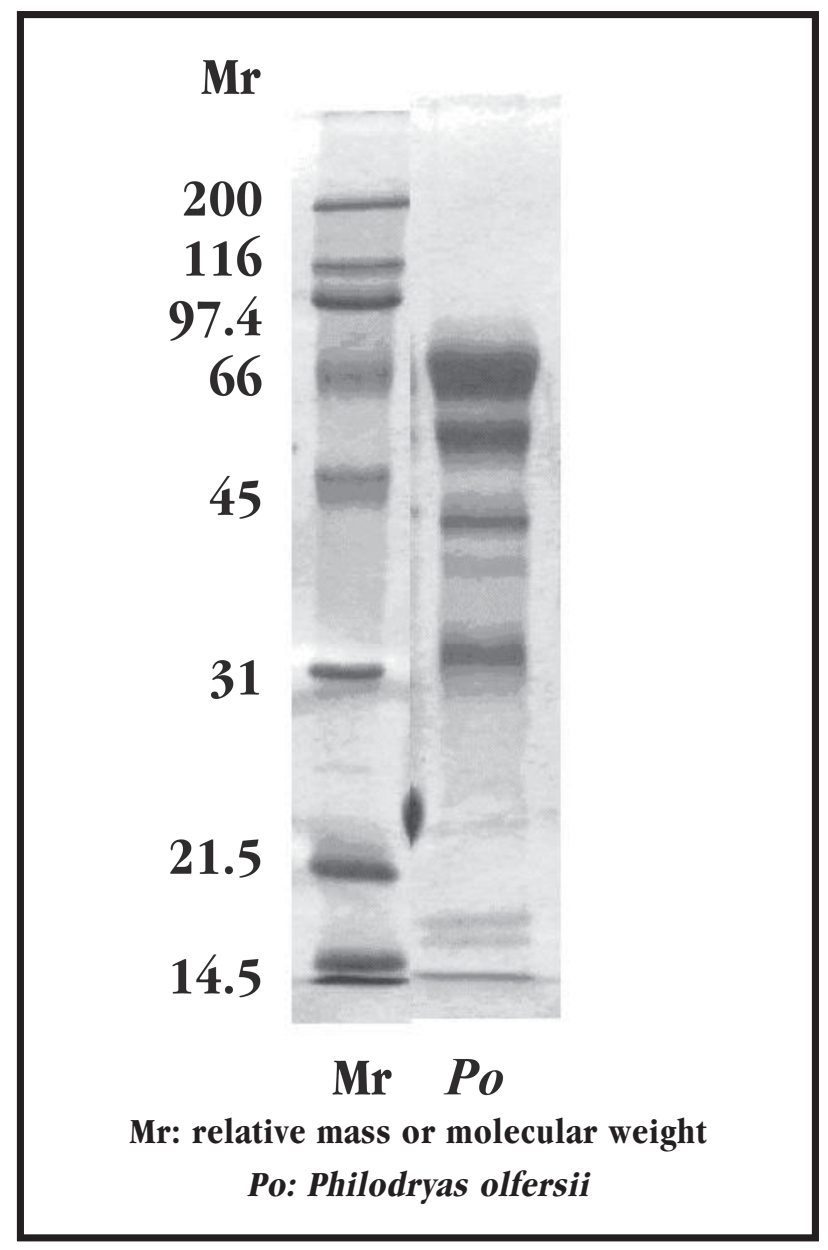

Figure 1- Philodryas olfersii venom run in a $20 \%$ polyacrylamide gel electrophoreses (SDS-PAGE)
Ionic interchange chromatography. Philodryas olfersii venom run on a Mono Q2 column chromatography produced nine peaks (Figure 2). The eluting peaks were tested for proteolytic activity.

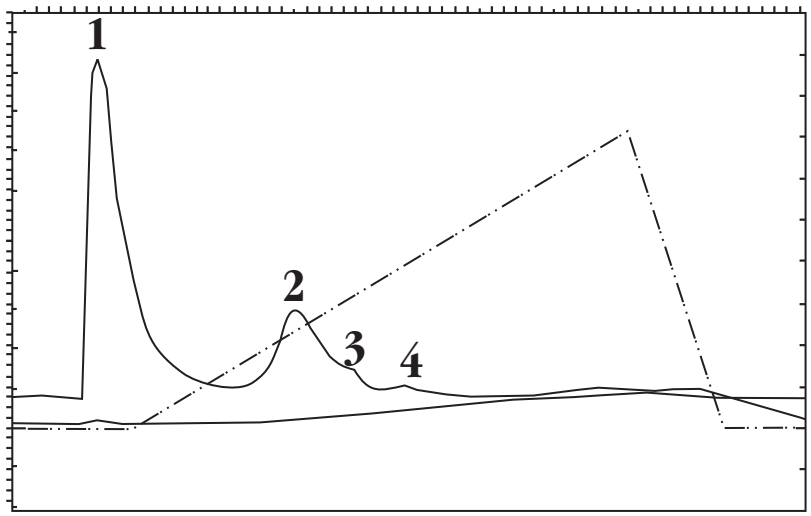

Figure 2- Separation of Philodryas olfersii venom fractions by ion-exchange chromatography on a MonoQ2 column. VENOM (20mg) was dissolved in $1.0 \mathrm{ml}$ of 50mM Tris-HCl buffer, $\mathrm{pH}$ 7.0, and loaded on a column equilibrated with the same buffer. After elution of unbound material, a lineal NaCl gradient from 0-1M pH 7-9 was developed. Peaks 1, 2 and 4 showed proteolytic activity.

Haemorrhagic activity tested on chicken embryos. Figure 3 shows the haemorrhagic activity of crude Philodryas olfersii venom on the chicken embryo vitelline vein. An obvious vascular blood extravasation was observed. Saline solution negative control and Bothrops venezuelensis venom positive control were also demonstrated.

Determination of haemorrhagic activity on mouse skin. Philodryas olfersii venom showed haemorrhagic activity when tested by intradermal injections in mice (Figure 4). The minimum haemorrhagic dose was $24 \mu \mathrm{g}$, indicating that this venom was less active than crude Bothrops venezuelensis positive control venom $(\mathrm{MHD}=5.6 \mu \mathrm{g})$.

Determination of haemorrhagic activity on mouse peritoneum. All mice intraperitoneally injected with Philodryas olfersii venom showed intense haemorrhagic activity; saline solution negative control and Bothrops venezuelensis venom positive control were also determined (Figure 5).

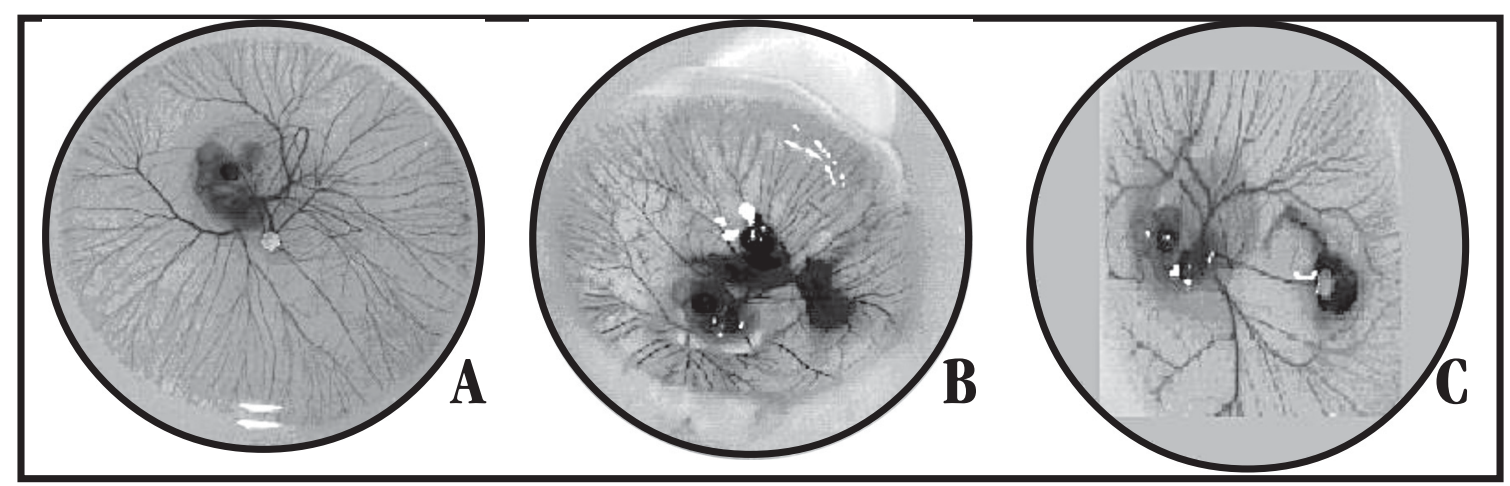

Figure 3- Philodryas olfersii venom haemorrhagic activity in chicken embryos. A: Negative control (Saline solution); B: Positive control (Bothrops venezuelensis venom); C: Philodryas olfersii venom. 

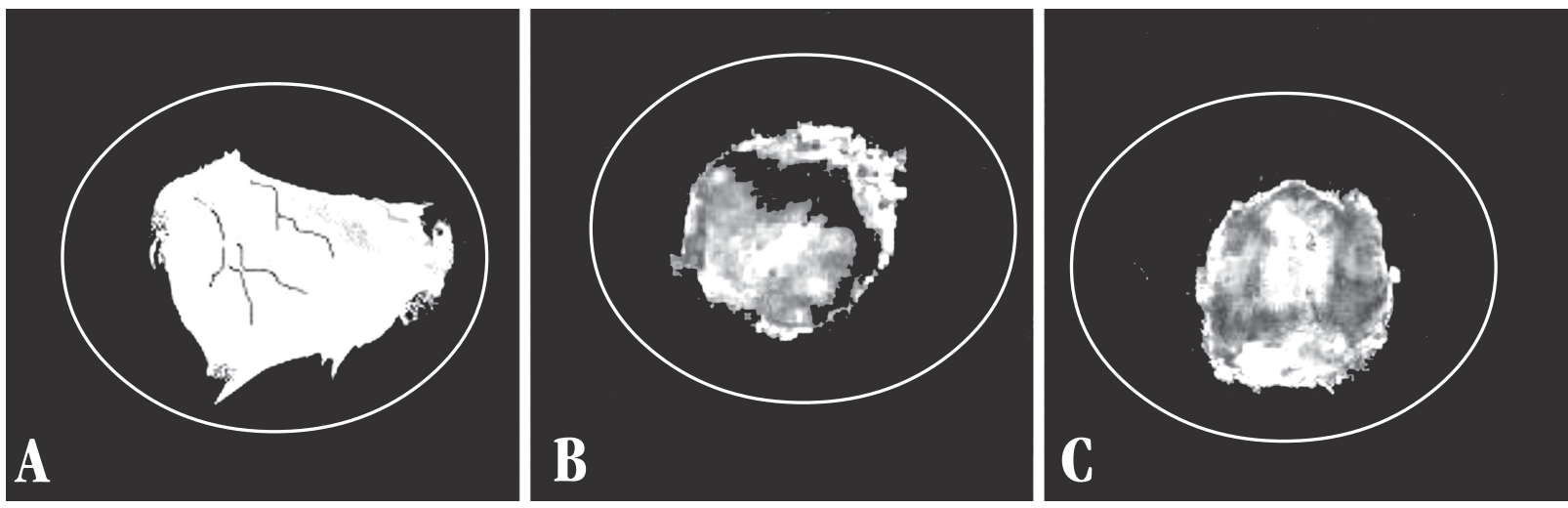

Figure 4- Philodryas olfersii venom haemorrhagic activity on mice skin. A: Negative control (Saline solution); B: Positive control (Bothrops venezuelensis venom); $C$ : Philodryas olfersii venom.

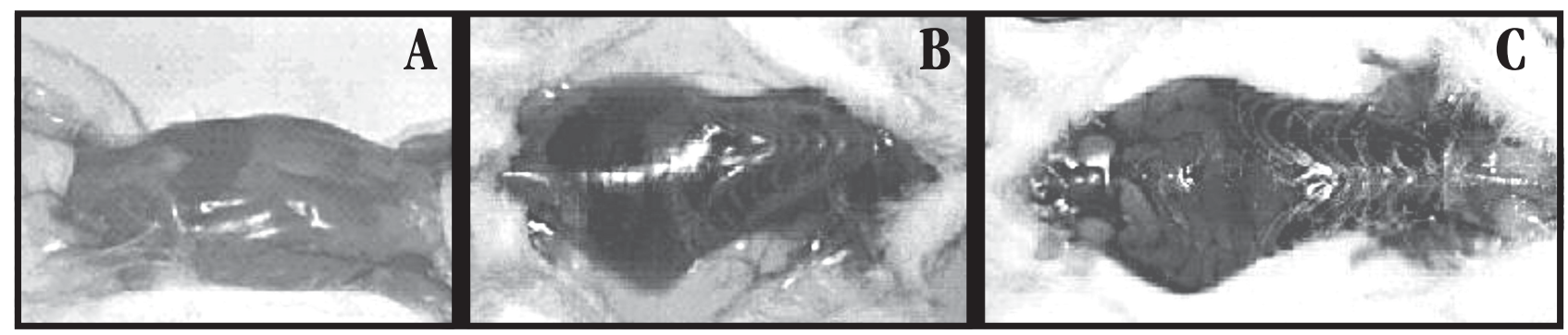

Figure 5- Philodryas olfersii venom haemorrhagic activity in the peritoneum. A: Negative control (Saline solution); B: Positive control (Bothrops venezuelensis venom); $\boldsymbol{C}$ : Philodryas olfersii venom.

Proteolytic (gelatinase) activity. The peaks obtained by chromatography and the secretion from crude venom were set on X-ray film showing the proteolytic activity of the crude venom up to dilutions of 1:128. Chromatography corresponding to peaks at P1, P2 and P4 demonstrated proteolytic activity: peak P1 up to dilutions of 1:128; P2 up to dilutions of 1:8 and P4 up to dilutions of 1:2.

Neurotoxic activity. Philodryas olfersii venom neurotoxic activity was demonstrated by observing several neurological manifestations of six mice subcutaneously injected develop during the experimental period (Table 1).

Table 1 - The results represent a pool of signs and symptoms of neurotoxic activity from 6 mice intraperitoneally inoculated with Philodryas olfersii venom.

\begin{tabular}{|c|c|c|c|c|c|c|}
\hline $\begin{array}{l}\text { Time } \\
(\min )\end{array}$ & Dyspnea & $\begin{array}{l}\text { Equilibrium } \\
\text { alterations }\end{array}$ & $\begin{array}{c}\text { Posterior } \\
\text { limbs } \\
\text { paralysis }\end{array}$ & $\begin{array}{c}\text { Flaccid } \\
\text { paralysis }\end{array}$ & $\begin{array}{l}\text { Urinary } \\
\text { sphincter } \\
\text { relaxation }\end{array}$ & $\begin{array}{c}\text { Time } \\
\text { of } \\
\text { death } \\
\end{array}$ \\
\hline 2 & & $1 \mathrm{~s}, 3 \mathrm{~s}$ & & & & \\
\hline 6 & & $5 s, 4 s, 6 s$ & $2 \mathrm{~s}, 4 \mathrm{~s}, 6 \mathrm{~s}$ & & & \\
\hline 8 & & & $1 \mathrm{~s}$ & $2 s$ & & \\
\hline 15 & $2 \mathrm{~s}, 5 \mathrm{~s}$ & & $5 \mathrm{~s}$ & $5 s$ & $2 \mathrm{~s}, 5 \mathrm{~s}$ & $2 \mathrm{~s}$ \\
\hline 20 & & & & & & $5 s$ \\
\hline \multicolumn{7}{|l|}{23} \\
\hline 33 & $3 \mathrm{~s}, 4 \mathrm{~s}$ & & & $3 \mathrm{~s}, 4 \mathrm{~s}$ & & \\
\hline 53 & $1 \mathrm{~s}, 6 \mathrm{~s}$ & & & $1 \mathrm{~s}$ & $3 \mathrm{~s}, 4 \mathrm{~s}$ & \\
\hline 63 & & & & $6 s$ & $1 \mathrm{~s}$ & $3 \mathrm{~s}, 4 \mathrm{~s}$ \\
\hline 68 & & & & & & $1 \mathrm{~s}, 6 \mathrm{~s}$ \\
\hline
\end{tabular}

\section{DISCUSSION}

The biological role of neurotoxicity in $P$. olfersii is unknown, as is the case with most Colubridae. Nevertheless, neurotoxic activity in venoms is most reliable in the role of killing or debilitating a victim, rather than for digestion or some other purpose ${ }^{9}$.

The different effects of Philodryas olfersiivenom were studied in vivo in mice and chicken embryos, as well as on Kodak film with gelatine coating. Chicken embryos were used to measure haemorrhagic activity and antivenin efficiency in Viperidae and Elapidae venom ${ }^{26}$. This is the first time that this method has been incorporated in Philodryas venom studies, demonstrating its high haemorrhagic activity. In Venezuela, only a few authors ${ }^{25}$ have described a number of electrophoretic and biological characteristics of Philodryas viridissimus venom. These authors found that $P$. viridissimus venom fractions shared the same molecular weight with some Crotalus venom fractions and they corresponded to proteolytic venom enzymes already described. In the current work, peaks 1, 2, 3 and 4 from Philodryas olfersii obtained by ion interchange chromatography, demonstrated a strong gelatinase activity caused by at least 3 peaks, peak 1 presented the highest activity (1:128 dilutions). Other researchers ${ }^{4523}$ make reference to the strong proteolytic activity of Philodryas olfersii and likewise refer to the fibrin(ogen) olytic activities and myotoxic effects, apparently caused by at least one other component of the venom. 
In the present work using mice, the peritoneum and skin haemorrhagic activity produced by Philodryas olfersii venom was also clearly shown, indicating that this Colubridae possess a very strong haemorrhagic action on mammalian tissues. The haemorrhage seen in the vitelline vein of chicken embryos also indicated the strong proteolytic activity on the vasculature. The nature of this and other components from the venom of colubrids that cause similar effects remain unknown. Assakura et $\mathrm{al}^{4}$ described a partially purified (HPLC) Philodryas olfersii venom haemorrhagic enzyme producing large haemorrhagic areas.

In the neurological assay, it was observed that Philodryas olfersii venom produced several neurotoxic symptoms in the inoculated mice. To the best of our knowledge, this is the first time that these different in vivo neurological signs and symptoms produced by Philodryas olfersii venom have been described. In a review of the literature, only one work describing the activity on the neuromuscular junction ${ }^{23}$ was found. The most notable and initial activities were the equilibrium disorders, posterior limbs paralysis and flaccid paralysis, which occurred between two to six minutes after venom injection. Death, probably caused by respiratory paralysis, took place 15 min after venom injection.

For a long time opisthoglyphous snakes have been neglected by most physicians, since it was believed that their venom was of little importance and ineffective on humans, even though reports of human death envenomed by these harmless species have been published $^{1719}$. Many authors defined this venom as a Duvernoy's gland secretion, but this term no longer applies to the colubrid families, as the glands were shown to be the same venom gland found in Atractaspididae, Elapidae and Viperidae?.

The results obtained here regarding haemorrhagic, neurotoxic and proteolytic activities were much more convincing than expected. This should serve as a warning to medical specialists regarding the toxic potential that these species possess $^{1322}$.

\section{REFERENCES}

1. Aguilar I, Girón ME, Rodríguez-Acosta A. Purification and characterisation of a haemorrhagic fraction from the venom of the Uracoan rattlesnake Crotalus vegrandis. Biochimica et Biophysica Acta 1548: 57-65, 2001.

2. Anonymous. Principles of laboratory animal care. National Institute of Health of United States. Maryland USA, Pub. 85-23, 1985.

3. Araujo ME, Santos AC. Cases of human envenoming caused by Philodryas olfersii and Philodryas patagoniensis (Serpentes: Colubridae). Revista da Sociedad Brasileira de Medicina Tropical 30: 517-519, 1997.

4. Assakura M, Reichl P, Mandelbaum FR. Isolation and characterization of five fibrin(ogen)olytic enzymes from the venom of Philodryas olfersii (green snake). Toxicon 32: 819-831, 1994.

5. Assakura MT, Salomao MG, Puorto G, Mandelbaum FR. Hemorrhagic, fibrinogenolytic and edema-forming activities of the venom of the colubrid snake Philodryas olfersii (green snake). Toxicon 30: 427-438, 1992.
6. Broaders M, Ryan MF. Enzymatic properties of the Duvenoy's secretion of Blanding's tree snake (Boiga blandingi) and of the mangrove snake (Boiga dendropila). Toxicon 35: 1143-1148, 1997.

7. Campbell JA, Lamarck WW. The venomous reptiles of Latin America. Cornell University Press, Ithaca, New York, 1989.

8. Donelly MA, Myers CW. Herpetological results of the 1990 Venezuelan expedition to the Summit of Cerro Guaiquinima, with new Tepui reptiles. American Museum Novitates 3017: 1-54, 1991

9. Fry BG, Lumsden NG, Wúster W, Wickramaratna JC, Hodgson WC, Kini RM. Isolation of a neurotoxin (alfa-colubritoxin) from a nonvenomous colubrid: evidence for early origin of venom in snakes. Journal of Molecular Evolution 57: 446-452, 2003.

10. Gutierrez JM, Leon G, Rojas G, Lomonte B, Ruvacado A, Chaves F. Neutralization of local tissue damage induced by Bothrops asper (terciopelo) snake venom. Toxicon 36:1529-38, 1998

11. Huang SY, Perez JC. Comparative study on hemorrhagic and proteolytic activities of snake venoms. Toxicon 18: 421-426, 1980.

12. Huang SY, Perez JC. A comparative electron microscopic study of myonecrosis induced by Crotalus atrox (Wester Diamondback Rattlesnake) in gray woodrats and mice. Toxicon 20: 443-449, 1982.

13. Jaume ML. Notas sobre mordeduras tóxicas de serpientes (Reptilia-SerpientesColubridae). Revista Cubana de Medicina Tropical 35: 224-230, 1983.

14. Kondo H, Kondo S, Ikezawa H, Murata R, Ohsaka A. Studies on the quantitative method for determination of hemorrhagic activity of habu snake venom. Japanase Journal of Medical Sciences and Biology 13: 43-49, 1960.

15. Kuch U, Jesberger U. Human envenomation from the bite of the South American colubrid snake species Philodryas baroni Ber, 1895. The Snake 25: 63-65, 1993.

16. Laemmli UK. Cleavage of structural proteins during the assembly of the head of bacteriophage T4. Nature 227: 680-685, 1970.

17. Lancini AR. Serpientes de Venezuela. In: Armitano E (ed) Familia Colubridae, Caracas, Venezuela, p. 89, 1979.

18. Lowry $\mathrm{OH}$, Rosembrough NJ, Farr AL, Randall RJ. Protein measurement with the folin phenol reagent. Journal of Biological Chemistry 193: 265-272, 1951.

19. McKinstry DM. Evidence of toxic saliva in some colubrid snakes in the United States. Toxicon 16: 523-534, 1978.

20. Navarrete LF, Lemoine K, Rodriguez-Acosta A. Is the opistoglyph Clelia clelia Duvernoy's gland secretion haemorrhagic in humans? Acta Biologica Venezuelica 19: 19-23, 1999.

21. Perez OA, Vila LL, Peichoto ME, Marunak S, Ruiz R, Teibler P, Gay C, Rey L. Edematogenic and myotoxic activities of the Duvernoy's gland secretion of Philodryas olfersii from the north-east region of Argentina. Biocell 27: 363-370, 2003.

22. Poey F. Mordedura de un Jubo. El Genio Científico de la Habana 1: 94-98, 1873

23. Prado-Franceschi J, Hyslop S, Cogo JC, Andrade AL, Assakura M, CruzHoffing MA, Rodrigues-Simioni L. The effects of Duvernoy's gland secretion from the xenodontine colubrid Philodryas olfersii on striated muscle and the neuromuscular junction: partial characterization of a neuromuscular fraction. Toxicon 34: 459-466, 1996.

24. Ribeiro LA, Puorto G, Jorge MT. Bites by the colubrid snake Philodryas olfersii: a clinical and epidemiological study of 43 cases. Toxicon 37: 943-948, 1999.

25. Rodriguez-Acosta A, Girón ME, Aguilar I, Fuentes O. A case of envenomation by a "non venomous" snake (Philodryas viridissimus) and comparison between this snake Duvernoy's gland secretion and northern South America rattlesnakes venoms. Archivos Venezolanos de Medicina Tropical 1: 29-32, 1997.

26. Sells PG, Richards AM, Laing GD, Theakston RDG. The use of hens'eggs an alternative to the conventional in vivo rodent assay for antidotes to haemorrhagic venoms. Toxicon 35: 1413-1421, 1997.

27. Wenstein SA, Kardong KV. Properties of Duvernoy's secretions from opisthoglyphous and aglyphous colubrid snakes. Toxicon 32: 1161-1185, 1994. 